\title{
DÜBLIN
}

Technological University Dublin ARROW@TU Dublin

1996

\section{Alternatives to Antibiotics}

John MCKenna

Follow this and additional works at: https://arrow.tudublin.ie/irckbooks

Part of the Arts and Humanities Commons

\section{Recommended Citation \\ MCKenna, John, "Alternatives to Antibiotics" (1996). Cookery Books. 74. \\ https://arrow.tudublin.ie/irckbooks/74}

This Book is brought to you for free and open access by the Publications at ARROW@TU Dublin. It has been accepted for inclusion in Cookery Books by an authorized administrator of ARROW@TU Dublin. For more information, please contact arrow.admin@tudublin.ie, aisling.coyne@tudublin.ie, gerard.connolly@tudublin.ie.

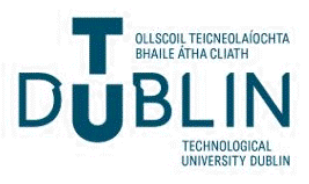




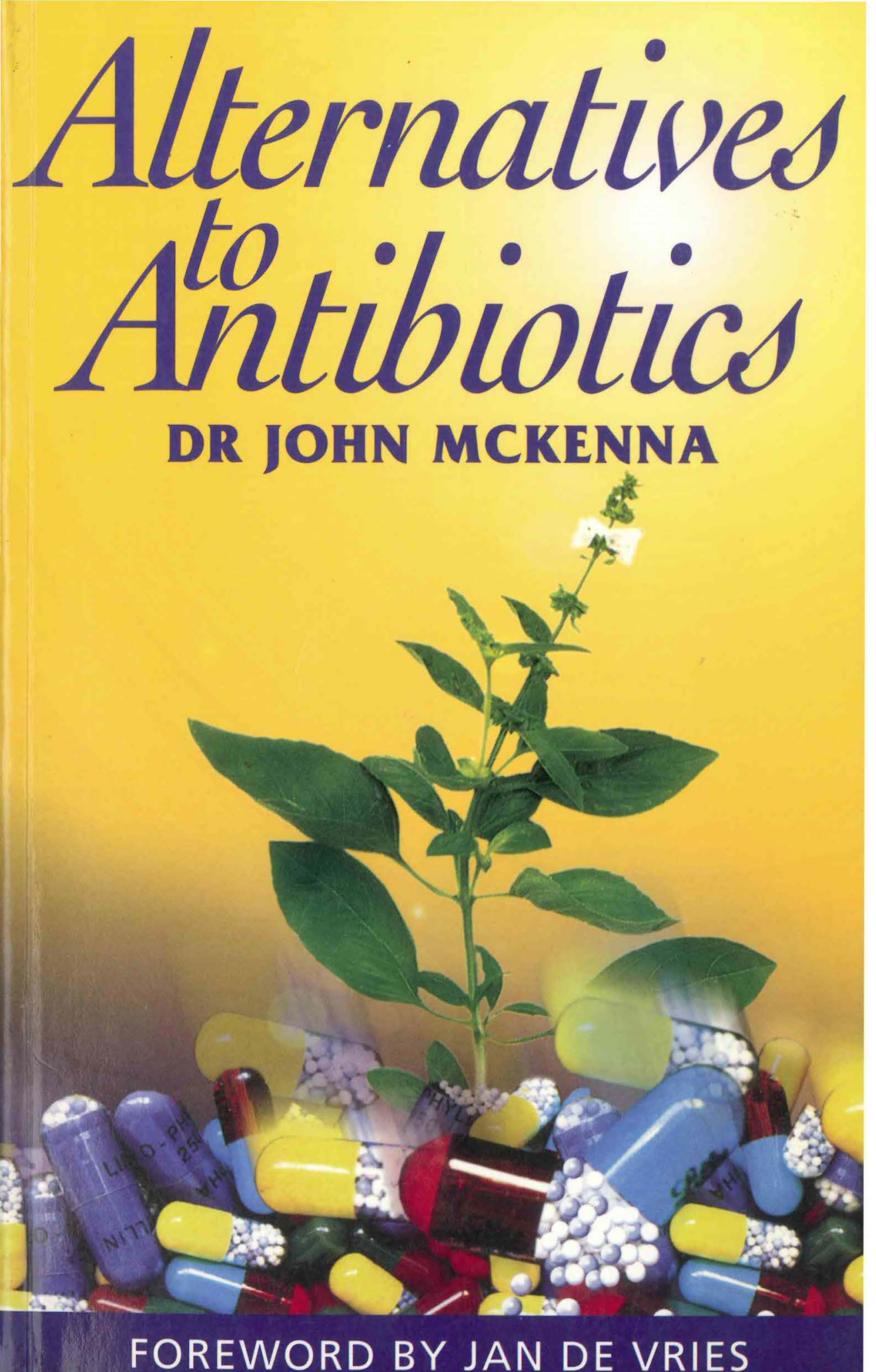




\title{
Alternatives to Antibiotics
}

\author{
Dr John McKenna
}


Gill \& Macmillan Ltd

Goldenbridge

Dublin 8

with associated companies throughout the world

(C) John McKenna 1996

$071712469 \mathrm{X}$

Index compiled by Helen Litton

Print origination by O'K Graphic Design, Dublin

Printed by ColourBooks Ltd, Dublin

All rights reserved. No part of this publication may be copied, reproduced or transmitted in any form or by any means, without permission of the publishers.

A catalogue record for this book is available from the British Library.

$\begin{array}{lllll}1 & 3 & 5 & 4 & 2\end{array}$ 


\section{Contents}

Foreword

ix

Preface

xi

Acknowledgments

XV

Introduction

xvii

1. The History of Antibiotics

2. Bacterial Resistance to Antibiotics

3. The Use and Abuse of Antibiotics

4. Conventional and Alternative Medical Approaches 40

5. Childhood Infections

6. Herbal Medicine

7. Homeopathic Medicine

8. Nutritional Medicine

9. Nutritional Supplements

10. The Role of Stress

Conclusion

Bibliography

Index 


\section{Foreword}

It was after a talk in Dublin that I first had the pleasure of meeting Dr John McKenna. During our conversation, John told me he was writing this book-its publication could not have come at a more important time. It is a long-awaited and necessary book which addresses many issues and answers many questions.

Nowadays, people have a better understanding of the side effects related to the long-term use of antibiotics. Back in 1958, when I graduated in pharmacy, it was not an issue of public concern. The issue was in my mind even then, however. At that particular time there was an explosion in the use of antibiotics, tranquillisers and sleeping tablets. Since then, development of these drugs has continued unabated and today, when I look at the numerous patients I treat in my seven British clinics, I understand even better what I saw happening in the late fifties.

This book describes the many alternatives available. Echinacea, for example, was recently shown to be one of the best natural antibiotics in a study at the University of München in Germany. My own partner, Dr Alfred Vogel, now ninety-five years old and still skiing, has been promoting Echinacea for more than forty years and I am delighted that he can now see a scientific report validating the great benefits of Echinacea. This report proves that there are natural ways to support and boost the defences of the human body.

Some time ago I was asked to speak to a group of doctors and medical students in Germany. While talking about the immune system, I briefly mentioned a product called Echinaforce, the fresh herb extract from Echinacea purpurea. The doctors in question were very interested in 
the methods I have been using, during the past thirty-five years, to help human suffering. I was especially pleased when at the end of my lecture one doctor stood up to endorse what I had said about Echinacea. Apparently, while travelling in Brazil she had acquired a nasty throat infection. As there was no pharmacy nearby she was unable to obtain antibiotics, so she bought a bottle of Echinaforce in a simple health food store instead. She took twice the recommended dosage as she believed it could not do the job and found, to her surprise, that her sore throat had eased considerably by evening. Since then she has prescribed Echinacea to many of her patients, with great success.

This clear and concisely written book is a timely reminder of the great possibilities that nature has to offer. Nature is balanced and will always have the power to heal. The many subjects that Dr John McKenna has discussed in this book open the way to a greater recognition and understanding of natural remedies. After all, we are born in nature and have to obey the laws of nature if we want to stay healthy and fit. I am happy to see more and more people throughout the world becoming aware of the natural options available to them, instead of using and abusing synthetic antibiotics.

I am sure that the readers of this book will be impressed and rewarded by the tremendous research and knowledge that has gone in to its publication.

Jan de Vries D.Ho.Med., D.O.M.R.O., N.D.M.R.N., D.Ac., M.B.Ac.A. 